\title{
Some remarks concerning the indicators for appreciation the performance and the value created by the enterprise
}

\author{
Doina Pacurari, Universitatea Vasile Alecsandri din Bacau \\ Mircea Muntean, Universitatea Vasile Alecsandri din Bacau
}

\begin{abstract}
The appreciation of the performances of the enterprise are made, as a rule, by ways of indicators which are of accounting type, the result of financial exercise, profit or loss, being mostly used. This result can be determined differently, according to approaches of patrimonial, economic or financial nature. Due to the handling potential of this indicator, the attention of the analysts focused in time also on other computing patterns, uninfluenced by the accounting methods and techniques used by the enterprise. The investors' need of information determined the conception of some performance computing models based on the concept of creating value for the shareholders. Among these, those which express the ability of the enterprise to create value on long term, based on discounted cash flow, are the most appreciated. Nevertheless, within the Romanian economic context, the most used performance indicators are still of accounting nature for being accessible and understandable.
\end{abstract}

\section{Key-words}

performance, classical indicators, result, creating value, modern indicators

JEL Code: G32, L25, O12

\section{Introduction}

In business, the concept of performance can be translated by success obtained either generally or in the specific field of activity of the enterprise. The quantification of this succes cab be made through a series of qualitative and quantitative indicators such as: turnover, market quota, operating cash flows, added value, personnel qualification, reputation of the managers' team, social climate, etc. However, the main indicator, unanimously accepted, for assessing the performances of the enterprise remains its accounting result (we consider that the term result has a wider meaning than income, the last one suggesting more a favorable result).

If, by the middle of the $80 \mathrm{~s}$, the main performance indicator followed by the users of financial statements was the net result, the suspicions concerning its manipulation through various techniques of accounting nature, have determined, in the first stage, an interest increase in other result indicators as the operating result or the gross operating surplus (equivalent to the term anglo-saxon Earnings Before Interest Taxes Depreciation and Amortization). The last ones allow a better comparison of performances of various enterprises by means of elimination of fiscal incidence (if the tax is calculated for global business), of financial and extraordinary elements, of provisions, etc.

Among the factors that can influence the performance of an enterprise we can rank: the activity structure, the technological process, the materials used, the access to resources, the capacity of using the fixed assets, the quality of the employees, etc. The information about the performance of an enterprise, mostly its profitability, is necessary for: 
- the evaluation of potential changes of economic resources which the enterprise can controll in future;

- the anticipation of enterprise's ability to generate cash flows by using the available resources;

- the formulation of reasonings regarding the efficency of the enterprise to use new resources.

However, from the investors' point of view, as the main category of users according to anglo-saxon approaches, the performance aims the earnings per share and more, the dividend per share. Gradually the notion of shareholder value has been imposed.

Nowadays, there are numerous models of creating value and of appreciation of the enterprise' profitability. Among the modern indicators used in appreciation of performances there are: economic value added, market value added, total shareholder return, cash flow return on investement, and so on.

Due to the fact that the classical performance indicators offer limited information, the concept of value creating had become an integral part of managerial culture, and we can speak of ,value based management”, with the following advantages:

- ability to maximise the creation of value;

- improvement of decision making;

- encouragement of profitable investments leading to increase of value;

- improvement of resources allocation;

- setting clear objectives focused on the increase of the entity value;

- improvement communication with the investors and analysts.

The methods of performance analysis based on the concept of shareholder value became a necessity during the $90 \mathrm{~s}$, because of numerous critics with regards to the limits and subjectivity of the classical indicators.

Even though there are important differences between the methods and that it can be difficult to put them in practice, the main objective remains the measurement of the shareholder value and its maximization.

\section{Classical indicators of the enterprise' performance}

The main indicator of the performance of the enterprise is the result (profit or loss). It is an accounting model. Its value and formation are presented in the financial statements of the enterprise. The main advantage of the classical indicators relies on the fact that, due to its prolonged use, the majority of the people concerned is familiar with their computing method and can interpret their value.

The classical approach of performance, mainly of the result, aims at three aspects:

a) patrimonial - by means of the same evaluation method, the value of the enterprise is compared at two different moments.

The result of the exercise $\mathrm{N}$ is determined as a difference between the equity (Eq) registered at the end of exercises $\mathrm{N}$ and $\mathrm{N}-1$, more precisely the result shows the increase or decrease of value of the equity between the beginning and the end of the exercise $\mathrm{N}$ :

$$
\text { Result of exercise } N=E q_{N}-E q_{N-1}=\Delta E q
$$

Considering that the value of the equity can be influenced during the course of the year by contributions from the owners (capital increases by: contributions in cash and/or in kind, conversion of debt) or in favour of the owners (quota distributions, capital decreases), changes that do not relate to the result of the exercise, the equation becomes:

$$
\begin{gathered}
\text { Result of the exercise } N=\Delta E q-\text { Owners' contributions + Distributions in owners' } \\
\text { favour }
\end{gathered}
$$

This approach can lead to different values of the result during inflationary periods because the adjustments brought to different patrimonial elements, following the variations in prices, can be done by various methods, In such cases, supplimentary information regarding the 
methods of evaluation used, offered through explanatory notes, can reduce to some extent the degree of incertainty of the users.

b) economic - the result is determined as the difference between revenues and expenses:

Result of exercise $N=$ Revenues of exercise $N$-Expenses of exercise $N$

The economic approach can be controversed following the way of recognition of the revenues and expenses but also of the way of connecting expenses to revenues.

c) financial - the result is the expression of variation of the treasury of the enterprise during the reporting period, computed by the comparison of cashing and cash payment flows.

The result, expressed by the variation of the treasury (cash), is determined as a difference between the self-financing capacity, as security collected during the financial exercise and the computed expenses, that do not result in cash flows but correspond to real depreciation or probable risks:

\section{Result of exercise $=$ Self-financing capacity - Computed expenses}

The concept of result is accompanied, however, by a touch of subjectivity in relation to the interest of each category of users. For instance, with regards to the users' view about the result measured through traditional methods, the investors are interested, as shown before, by the net profit and its distribution as dividends, while the creditors are more interested by the gross result before the interest' payment.

Regarding the policies and accounting options adopted by the enterprise (stock evaluation, depreciation methods, etc.), the result can be different, and the enterprise, the management respectively, will follow its own interests (maximization of profit with the aim of presenting a better ,image” or, on the contary, the reduction of profit with the purpose of tax relief, etc ) The resilient character of the result limits the informational value of the profit and loss account. In order to avoid drawing erroneous conclusions based on this summary document, the user must analyse the methods and the accounting policies adopted by the enterprise and their impact on the reported result.

Other accounting indicators used in appreciation of performance of the enterprise are the operating result and the gross operating surplus (corresponding to EBITDA, Earnings Before Interest Taxes Depreciation and Amortization, used in anglo-saxon models). Their advantage relies on the fact that they cannot be handled by various accounting techniques of registering the provisions and of the adjustments of assets' value. Moreover, they are not influenced by the level of fiscality (insomuch as the tax is computed globally for the entire activity of the enterprise). The only element by which one can intercede over the value of these indicators is represented by the cost of sold goods, influenced by the method of valuation of stocks.

A better appreciation of the performance of the enterprise can be achieved by means of return ratio. It is common knowledge that these ratio allow comparisons in time and space, due to their way of computating namely by the effects obtained related to the efforts corresponding these effects. The main return ratio are: economic return (determined as ratio between the operating result and the value of enterprise assets and known as Return on Assets, ROA) and financial return (determined as ratio between the net result and the value of own capital and known as Return on Equity, ROE). Obviously, the investors are interested in the financial return of the enterprise, as expressing the theoretical ability to distribute dividends.

\section{Modern indicators of appreciation of created value by the enterprise}

It is a known fact that the basic obligation of the management of any enterprise is to make operational, investment and financial decisions that will ensure the long-term growth of the shareholders' wealth. The modification of the value of the own capital, together with the result by share, indicates the evolution of which this shareholders' wealth has registered during a period of time. 
If we refer to the accounting value of shares, based on the own capital presented in the financial statements, this is a measure subject to distortion. Since it represents a residual value, the net assets is affected by all past and future accounting adjustments, as well as by the more and more complex way to recognise changes of value for assets and liabilities. In conclusion, in the majority of cases in which the issue of economic analysis occurs the relevance of this indicator is doubtfull.

A series of indicators imposed over the last years as forms of expressing the new value created by the enterprise for its shareholders. We can rank, among these, the discounted cash flow, the economic profit, economic value added, market value added, the total shareholders return.

The novelty of the computing models of the created value in relation to the traditional methods of establishing performance is the fact that they lay emphasis on the cost of capital entirely.

The discounted cash flow (DCF) (a concept developped by Alfred Rappaport in his work „Creating Shareholder Value: the new standard for business performance”, known also under the term of ,shareholder value") allows appreciation of the value of the shareholders' participation to the enterprise's activity and offers thus information regarding the substantiation of strategic decision making. The indicator is obtained following the discount of the future forecast cash flows in correspondence with the cost of capital (of the investments made). The cash flows considered are whose related to operating activities in a certain period of time, without being influenced by the cash flows related to financing (interests, dividends, etc.). It is considered the best financial indicator for the appreciation of the enterprise's ability to create value for its owners. However, due to the fact that the forecast of the future cash flows is difficult to achieve by external analysts, DCF remains a less used indicator.

The measurement of the economic profit (EP) represents another method for determination the value created, having its roots in the „residual income" mentioned by the economist Alfred Marshall at the end of the 19th century and seen as the pay of some enterprises owner for the invested capital and the planning work, control and supervision.

The economic profit indicates the result obtained throughout the period, after covering all expense, including the expenses regarding the capital used. By comparison, the net profit doesn't take into account the cost of using the investors' capital, offering information that can mislead the users. Thus, some enterprises which are profitable from the point of view of the accounting result can be unprofitable from an economical point of view.

The economic profit is computed following:

$$
E P=(\text { Capital return }- \text { WACC }) x \text { Invested capital }
$$

where, WACC is weighted average cost of capital (the average ratio of total capital remuneration).

Difference between the capital return and his wieghted average cost is named "performance spread".

The economic profit value may be appreciated depending on certain key-factors that can be a basis for various objectives formulation regarding the performances:

- the capital return, in his turn influenced by the profit margin (profit/turnover) and the efficiency of developed activity (reflected by invested capital turnover);

- the ability of enterprise to generate turnover of capital use.

In 1991, the economic profit was redefined by the members of Stern Steward \& Co and thas a new concept has been developed: economic value added (EVA). By definition, EVA is the difference between the net operating profit (after tax) and the opportunity cost of capital used:

$E V A=$ Net operating profit - Invested capital $x$ Capital cost ratio

EVA, a financial accounting type indicator, is a measure of the financial performance by reflecting the economic profit of the enterprise and being direct related to the wealth creation for shareholders of time. That is to say that EVA reflects the measure in which the obtained 
result exceeds or is lower than the minimum rate of payment required by the creditors and investors for investment projects with similar risk.

By way of defining, EVA give a lot of attention to the cost of capital. The business enterprise must generate a rate of return at least equal with the market one, obtained in similar risk conditions. Otherwise, the accounting profit is unreal and irrelevant forasmuch the enterprise concerned does not create wealth for its owners but rather it acts in loss.

The relationship between EVA and DCF is simple. DCF is actually the sum of the future economic profits, discounted at weighted average cost of capital:

$$
D C F=\sum_{i=1}^{\infty} \frac{E V A_{i}}{(1+W A C C)^{i}}
$$

The economic value added allows the individual performance measuring, subject to the application of a required return ratio. EVA, like all yearly indicators with integral or partial accounting character, may be subject to distortion. Thus, it can try the maximization of EVA for a given year in detriment of the coming years. A high value of the indicator at one time does not indicate the long-term wealth creation. Therefore, only the discounted future cash flows may reflect the enterprise's ability to create sustainable value.

The other indicator introduced by Stern Steward \& Co is Market Value Added (MVA), especially applicable for listed companies. MVA indicates the surplus of the total market value over the invested capital value and reflects the appreciation of the enterprise on the capital market.

$$
M V A=\text { Market value of the company - Total invested capital }
$$

The market value of the company (market capitalisation) is calculated by multiplying the quotation with the number of shares that are in circulation (for the unlisted companies the market value is estimated on the basis of the present value of future cash flows generated for investors).

A positive MVA indicates a investment return higher than capital cost and also that the shares are trading at a higher price than initial capital.

The relationship between the last two indicators is the following:

$M V A=$ Discounted value of the future EVAs

The increase of EVA will be followed by an increase of the Market Value Added. Based on the above relationship, the market value of the own capital can be considered to be the present value of all future cash flows belonging to owners.

MVA (or rather change in MVA) represents a better criterion than quotation evolution because it connects the increasing of value with the capital invested to obtain it.

Another indicator, this time of stock type, to measure performance is total shareholder return (TSR) (proposed by Boston Consulting Group). TSR allows appreciation of the value obtained by the investors of share ownership and reinvestment of dividends in a certain period of time (at least one year). Indicator is the percentage and allow comparisons between companies or over the industry or market average. TSR is computed following:

$$
T S R=\frac{\left(Q_{1-} Q_{0}\right)+D i v}{Q_{0}} \times 100
$$

where:

$\mathrm{Q}_{1}$ - quotation at the end of the period

$\mathrm{Q}_{0}$ - quotation at the beginning of period

Div - amount of dividends (includes not only the distributed dividends but also the cash payments to shareholders and the repurchases of shares)

TSR is thus a actuarial rate of return to shareholders who bought shares at the beginning of period, determined by evaluating the own portofolio at the quotation valid to end of the period.

To be relevant, the calculation must be done for a long time (5-10 years) so as to eliminate the effect of non-systematic variations of quotation. 
For listed companies is also calculated and the price earnings ratio (PER), by dividing the share price to earnings per share. The profit taken into account is the last year profit of the common shares. PER allows comparisons with the average rate of a certain industry or market wide.

A synthesis of the main advantages and disadvantages of the above indicators is presented in the table below:

\begin{tabular}{|c|c|c|c|}
\hline \multicolumn{2}{|c|}{ Type of indicator } & \multirow[b]{2}{*}{$\begin{array}{l}\text { Advantages } \\
\text {-quick computing; } \\
\text {-extensive utilisation, } \\
\text { for all-types } \\
\text { enterprises; } \\
\text {-accesible to all } \\
\text { categories of users. }\end{array}$} & Disadvantages \\
\hline Accounting & $\begin{array}{ll}\text { - } & \text { Net result } \\
\text { - } & \text { Profit per share } \\
\text { - } & \text { Gross operating } \\
& \text { surplus } \\
\text { - } & \text { Operating result } \\
\text { - } & \text { Economic return } \\
\text { - } & \text { Financial return }\end{array}$ & & $\begin{array}{l}\text {-have not respect to: } \\
\text { required equity return, } \\
\text { cost of the own equity, } \\
\text { risks; } \\
\text {-except for rates of } \\
\text { return does not allow } \\
\text { relevant comparisons } \\
\text { in space (between two } \\
\text { or more enterprises); } \\
\text {-handling potential } \\
\text { through accounting } \\
\text { engineering. }\end{array}$ \\
\hline Financial & $\begin{array}{l}\text { - Discounted Cash } \\
\text { Flow }\end{array}$ & $\begin{array}{l}\text {-the best criterion for } \\
\text { apreciation the } \\
\text { enterprise's ability to } \\
\text { create value. }\end{array}$ & $\begin{array}{l}\text {-difficult computation, } \\
\text { especially for external } \\
\text { users. }\end{array}$ \\
\hline $\begin{array}{l}\text { Financial- } \\
\text { accounting }\end{array}$ & $\begin{array}{l}\text { - Economic Profit } \\
\text { (Economic } \\
\text { Value Added) }\end{array}$ & $\begin{array}{l}\text {-quite simple } \\
\text { computation; } \\
\text {-pay respect to } \\
\text { weighted average cost } \\
\text { of capital. }\end{array}$ & $\begin{array}{l}\text {-limited to one } \\
\text { financial exercise, his } \\
\text { trend being difficult to } \\
\text { measure. }\end{array}$ \\
\hline $\begin{array}{l}\text { Capital } \\
\text { Market }\end{array}$ & $\begin{array}{ll}\text { - } & \text { Total } \\
\text { Shareholder } \\
\text { Return } \\
\text { - } \\
\text { Market Value } \\
\text { - } \\
\text { Pdded } \\
\text { Price Earnings } \\
\text { Ratio }\end{array}$ & $\begin{array}{l}\text {-if TSR is computed } \\
\text { for a longer period of } \\
\text { time may be indicate } \\
\text { the real obtained } \\
\text { shareholder return; } \\
\text {-MVA is quite simple } \\
\text { to calculate and reflect } \\
\text { the total created value, } \\
\text { not only the annual } \\
\text { one. } \\
\text {-PER allows } \\
\text { comparative analyses } \\
\text { of domain or wide } \\
\text { stock market. }\end{array}$ & $\begin{array}{l}\text {-difficult to apply for } \\
\text { unlisted companies; } \\
\text {-in the short term may } \\
\text { be affected by capital } \\
\text { market volatility. }\end{array}$ \\
\hline
\end{tabular}

\section{Conclusions}

The constant concerns of theorists and practitioners for as accurate an assessment of the enterprises' performances lead to the definition of several indicators, some of accounting nature, others of financial and capital market nature. Over time, the analysts focused gradually from the intrinsic performance of the enterprise to the performance in benefit of the shareholders, by creating long term value. 
The best appreciation criterion of the ability of the enterprise to create value for its owners is based on updating the future cash flows generated by its economic activity. The computing model of the discounted cash flow is, however, difficult for external analysts, which significantly restricts the area of application of this indicator.

The indicators of type of capital market are adequate when analyzing the performances of the listed companies but still in a small number in the current economic context in Romania.

For the time being, the most used performance indicators are those of accounting nature due to their accesibility and intelligibility. Their use, when having sufficient information concerning the accounting principles and methods applied by the enterprise, allows the valuation of past performances and the estimate of future performances. These performances represent the expression of the enterprise's ability to create value for its owners. We feel that the analysts in our country could pay a greater attention to some indicators such as economic profit or economic added value, as these models take into account the total cost of the invested capital.

\section{Bibliography}

[1] Helfert, E., Tehnici de analiză financiară, BMT Publishing House, București 2006

[2] Jianu, I., Evaluarea, prezentarea şi analiza performanței întreprinderii: o abordare din prisma Standardelor Internaționale de Raportare Financiară, Ed. CECCAR, Bucureşti 2007

[3] Păcurari, D., Diagnostic şi strategie în societățile comerciale pe baza informațiilor de sinteză ale contabilității, Ed. Tehnopress, Iaşi 2009

[4] Păvăloaia, W., Paraschivescu, M.D., Olaru, G.D., Radu, F., Analiză financiară - studii de caz, Ed.Tehnopress, Iaşi 2006

[5] Petrescu, S., Analiză şi diagnostic financiar-contabil: ghid teoretico-aplicativ, ed.a II-a rev., Ed. CECCAR, Bucureşti 2008

[6] Quiry, P., Le Fur, Y., Pierre Vernimmen - Finance d'entreprise, $7^{\mathrm{e}}$ édition, Ed. Dalloz, Paris 2008

[7] Tracy, J.A., How to Read a Financial Report, $6^{\text {th }}$ edition, John Wiley\&Sons, 2004

[8] Williams, J.R., Haka, S.F., Bettner, M.S., Carcello, J.V., Financial accounting, $13^{\text {th }}$ edition, McGrow-Hill, N.Y. 2003 